Canadian Studies in Population, Vol. 32.2, 2005, pp. 137-153

\title{
Legacy of Enid Charles, 1894-1972
}

\section{Sylvia Wargon}

Statistics Canada

Ottawa, Ontario, Canada

Paper presented in the

Distinguished Demographer Lecture Series,

November 19, 2004

Sociology Department, University of Alberta, Edmonton, Alberta

\section{(Dorothy) Enid Charles 1894 - 1972}

In answer to the question: "Why the interest in the times, life and legacy of Enid Charles," an appropriate answer would be that:

- She was one of the earliest $20^{\text {th }}$ century pioneers (world-wide) in the field of demography, just then developing,

- She spent the years 1940 to 1946 in Canada, where she left an important legacy of research in fertility and nuptiality,

- The work she did for the World Health Organization (WHO) after 1953, undoubtedly her best work, is virtually unknown. 
Sylvia Wargon

Charles's began her university education with studies at Newnham College, Cambridge University, 1913-1916, and then spent ten months (1916-1917) at a Liverpool university settlement (Hogben 1998, 65). ${ }^{1}$ It was only in the early 1930s that she began to concentrate on the study of human population, and specifically, to specialize in the study of fertility and the preparation of population projections, two fairly "new" areas in demography that were just developing. These became her main interests, although her work was never limited solely to these subjects.

In the early 1930s, there were not many scholars who specialized in demography, and hardly any who were as interested as Charles was then, in the study of fertility. Years later, Eugene Grebenik reported that when he was a student at the University of London in 1937-38, in a course that Charles's husband (Lancelot Hogben) gave there, the number of students interested in demography could be counted

.....if not on the fingers of one hand, then certainly on the fingers of both... (Grebenik 1991, 8).

Before continuing, it is important to have some idea of the main trends and factors that shaped and influenced the society into which Charles was born, and in which she grew up, matured and was educated.

\section{Climate of the Times of Enid Charles}

Certain $19^{\text {th }}$ and early 20th century trends and factors that left visible traces on the demographic, social and intellectual climate of British society and the activities of individual scholars were reflected in Charles's professional work as a demographer and population statistics specialist from 1930.

First, there was the $19^{\text {th }}$ century development of the statistical movement, and an interest in the quantitative approach. These developments took hold initially in Great Britain rather than elsewhere in Europe, with the beginning in $17^{\text {th }}$ century Great Britain of political arithmetic that predated what became known, only in 1855 , as demography.

Then there was the development of a "belief in numbers" or statistics to document unfavourable social, health, and living conditions, because of the enormous commercial and industrial changes that revolutionized $18^{\text {th }}$ and particularly $19^{\text {th }}$ century Great Britain (See Cullen 1976). Assistance for the 
population groups (especially women and children) that made these changes possible, depended on the enactment politically, of appropriate public health, education and related reforms, usually promoted by the more advantaged classes. Members of various government departments, and locally organized (municipal/provincial) statistical societies that sprang up everywhere in the mid$19^{\text {th }}$ century, considered it their mandate to collect, organize and disseminate statistical information in studies on the population in their areas. Though shortlived, these activities were very important, and their permanent legacy has been called "...the indigenous tradition of empirical social research characteristic of British sociology..." (Cullen 1976, 149).

\section{The Woman's Question and Feminism.}

In the 19th century people spoke, in the singular, of "woman's rights," "woman's suffrage" and the "woman movement," to show the many ways women initiated civic rights, social freedoms, and so on. In the second decade of the $20^{\text {th }}$ century, the word "feminism" came into use, though it would be generations before it was used as frequently, and with the same meaning that it is used today.

The late $19^{\text {th }}$ and early $20^{\text {th }}$ centuries also saw the initiation, expansion and growth of knowledge in a number of old and new 'hard' and 'soft' scientific fields, like anthropology, biology, demography, genetics, psychology, sociology, etc. Although demography, the science of human population, like statistics, grew out of political arithmetic (that originated in Great Britain in the mid-17 $7^{\text {th }}$ century, thanks to the 1662 work of John Graunt), it was only in the late $19^{\text {th }}$ and particularly in the early $20^{\text {th }}$ century, that research on fertility and related fields like nuptiality, became important. In any case, in the early 1930s, when Charles's interest shifted to the study of human population in published studies, she concentrated on the study of fertility and the calculation of population projections.

Aside from these specialties, Charles was aware of developments in related fields, like genetics. This was not only because of her wide-ranging intellect, but also because her husband and his colleagues were contributing to new findings in this and related fields at the very time that she was conducting fertility research, and she was aware and understood the importance of, their findings (See Charles 1948, to mention only one example).

Lastly, Charles, like her generation of scholars, firmly believed that the purpose of science was to find "the truth," and that "science must serve society." (For e.g., See Dublin, 1966, 235). 
Sylvia Wargon

\section{The Importance of Eugenics.}

The term eugenics was coined by Francis Galton in 1883 to describe "the science of improvement of the human race germ plasm through better breeding..." (Conrad 1977, 143). During the first three decades of the $20^{\text {th }}$ century, the philosophy of eugenics was pervasive in western society; it had a powerful intellectual hold in Europe and North America (Kevles 1986), especially among those interested in the situation of the "less advantaged" social classes. Although the early eugenic ideals seemed to disappear from public view by the mid-1940s, social historians have documented related initiatives and practices that continued in Europe and North America, though in fairly altered form "... from its pre-war and early-war stance...", after the close of the Second World War.

...(A) new generation of eugenists was to advocate the control of reproduction... as an extension of individual freedom rather than as a part of an overall social strategy for improving the race. By the 1950s the ideology of the Eugenics Society had shifted significantly in this direction, leaving the 'old guard' in an isolated position.. (Jones. 1980, 155).

\section{Life and Accomplishments of Enid Charles}

\section{4-1918 Early Studies and Marriage}

(Dorothy) Enid Charles was born in Denbigh, North Wales, on December 29, 1894, the only daughter by second marriage of a clergyman, the Reverend James Charles. Apparently, his sole worldly ambition was that she should have a university education.

From 1913 to 1916 , when she was 18 to 21 years of age, Charles attended Newnham College, one of two colleges for women at the University of Cambridge (the other was Girton College). There she studied, or as they say at Cambridge, "read" mathematics, economics and statistics. After completing undergraduate studies in 1916, she went on to the University of Liverpool, for a one-year course, to gain a "university diploma of social science" (Hogben 1998, $65)$.

However, she returned home from a ten-month period at Liverpool, without completing the course of study, and in June 1917, she began to "cohabit" with Lancelot Hogben, whom she had met at Cambridge. In 1918, she married him, as they were expecting a child. It was a union of two very like-minded young people of the time, who viewed service to humanity as an important goal in life. 
Compared to other Newnham College graduates of the same period, Charles, at 23 , married at a much younger age than the average age of marriage of her peers, more resembling the 1950s generation. And Hogben, at marriage, was one year her junior, making his family indices as "avant-garde" as hers. In those days, men more frequently than today, reported a later age at marriage than their spouses.

\section{Education, Family Life and Travels 1918 - 1930}

Charles and Hogben had four children between 1918 and 1929; the youngest was born when they were in South Africa (more about that further on).

In the early 1920s, Cambridge abandoned a previous policy of not granting degrees to women. The MA was awarded if "...five years had elapsed since graduation as BA...", and on payment of a fee (Newnham College 1994). Therefore in 1923, after paying the fee, Charles could report that she was BA, MA (Cantab). Yet from the date of marriage in 1918 and during most of the 1920s, she did what just about all young mothers did then, and that some still do today, even those with university degrees: she bore and raised four children, while following her husband as he moved from one university appointment to another, sometimes crossing continents.

From 1925 to 1927, the family lived in Canada, where Hogben was Assistant Professor of Medical Zoology at McGill University in Montréal. After two years, in 1927, they left for the University of Cape Town, in South Africa.

On arrival there, they were faced with the 'tightening grip of apartheid.' Nevertheless, shortly after arrival, they resumed their (usual) Saturday evenings for social interchange, with a weekly "meeting" of Cape Town intelligentsia, including students. They were also fortunate in obtaining the services of a Swedish housekeeper, so Charles was able to spend full-time as a doctoral student in that period.

In South Africa, in 1929, Charles gave birth to their fourth (and last) child, a son, David Julian Lancelot. She also completed Ph.D studies at the University of Cape Town, submitting a doctoral dissertation in physiology, based on an idea from previous work by her husband. The thesis and some related articles, attribute authorship to "Enid Hogben." (This use of her married surname that neither she nor her husband condoned, was probably due to university practice at the time). These articles, some coauthored with her husband, documented research Charles carried out in the Department of Zoology's laboratory, at the 
Sylvia Wargon

University of Cape Town: some were published in South Africa in 1930, and some appeared from 1931 to 1933, in England.

The university graduation program (on Hogben's birthday - December 9) when Charles was 35, going on 36 years of age, noted that "...Dorothy Enid Hogben was conferred the Ph.D. in absentia." By that time, the family was either preparing to leave, or had already left, for England. The important thing was that Charles and Hogben were not sorry to depart. One of the main reasons for leaving, after only about 3 years' residence there, from 1927 to late 1930, was the gathering threat of apartheid (Wells 1978, 196).

Hogben had obtained an appointment at the University of London School of Economics and Political Science (LSE), as Head of the Department of Social Biology, thanks to Lord Beveridge, LSE's Director since 1919. In making his arrangements, Hogben had asked that "...Enid Charles be permitted to join the staff..." Charles had a long-standing interest in studying human population, and since Beveridge's main concern in promoting a chair in social biology was his preoccupation with population problems, Charles's "newly-found" interest in the study of human population was 'highly gratifying' to him.

\section{Family and Work in Great Britain 1930 - 1940}

In London, as Head of LSE's Department of Social Biology, Hogben brought together a number of individuals with special interest in demography (among them, R.R. Kuczynski) and, because he arranged a research fellowship for Charles, she became a member of this group (Grebenik 1997).

The change to a concentration on the study of human population in the early 1930s did not seem to "slow up" Charles's publication record. In 1932, she published the first concrete evidence of the change of specialty from physiology to human population, with the book: The practice of birth control: An analysis of the birth-control experiences of nine-hundred women (Charles 1932), for which Harold Laski wrote an "up-beat" foreword (Dahrendorf 1995, 257). ${ }^{2}$

Two years later, she published her better-known, second book, The twilight of parenthood: A biological study of the decline of population growth (Charles 1934a). In the same year, another edition, but without the subtitle, appeared in the U.S. only (1934b). In 1936, a reprinted version with a different main title, but with the identical subtitle and contents as the first edition, appeared as The menace of under-population: A biological study of the decline of population growth. 
The first (1934) edition of Charles's Twilight of parenthood aroused some controversy mostly because it went against the widely-accepted eugenic views held in Britain at the time. Charles had developed an intellectual position in opposition to eugenic principles, which she relentlessly opposed, and she did not hesitate to publicize her position in written and spoken form. Sixty years later, Keyfitz could still recall clearly that:

"...Charles took on the eugenicists in a battle where she was a minority against some of the most distinguished scholars of the day. It was generally accepted in the scholarly world that the better off were better endowed genetically, and that their low birth rate would surely lead to deterioration in the inherited qualities of the race. In my youth there were few to oppose this: Charles was one of these...(Keyfitz 1993)

There is ample evidence that others shared Charles's (and Hogben's) views on eugenics (Werskey 1978; Kevles 1986). Obviously, her book, involved her in one of the topical issues of the time, and in her characteristically forthright manner, she did not hesitate to state her position clearly and openly. Although the eugenic views that Charles had so vigorously opposed in the mid-1930s were discredited in the early 1940 s (because of the melding of early $20^{\text {th }}$ century eugenic principles with Nazi policies during the late 1930s and early 1940s), Charles was not vindicated. She was not congratulated for the courage she had shown in going against mainstream eugenic views in the mid-1930s. Probably this was because her 1934 projections for England and Wales, others in 1935 and those for Scotland in 1936, continued to arouse controversy. Based on the period 1921-1939, these early projections had 'missed entirely' the unexpected and enormous changes in patterns of marriage, births and average family size in the 1950s, the so-called baby and marriage booms. Much later (in the 1980s) the historian, Jane Lewis noted that Charles's 1934 projections "...made for sensational reading..." since they forecast that

...by the year 2033, the total population of England and Wales would be no larger than the county of London in 1934 (Lewis 1980, 104).

In a work four years later, Lewis referred to these projections as among the most widely discussed at the time (Lewis 1984, 38). Grebenik explained that one of her projections

...based on an extrapolation of the trend in age-specific mortality rates and fertility rates showed that the population of England and Wales which was 40.6 million in 1935, would fall to 17.4 million in 2000 and to 4.4 million in 2035, if age-specific mortality and fertility rates were to continue to fall at a rate in 
Sylvia Wargon

which Swedish age-specific rates had fallen between 1921 and 1931...(Grebenik 1991, 7).

Grebenik also noted -- in all fairness to Charles-- that, though she stressed that hers were hypothetical calculations on the basis of the period 1921-1939, the general public disregarded the small print and qualifications, and tended to treat her projections as "forecasts" (Grebenik 1991, 8).

In fact, other "predictions" of the time, made under the auspices of the Population Investigation Committee (the PIC), set up in 1935 by Carr-Saunders, were equally pessimistic and also attracted considerable publicity in the media (Lewis 1980, 39). Obviously, Charles's projections suffered the same fate and the same lack of public confidence as those prepared in the same period by other demographers, not only in Britain, but in other parts of the world. (See the appendices in the book by Notestein et al (Taueber, Kirk, Coale, and Kiser) 1944.

There is a record of Charles giving a talk as early as January 14, 1934, to the South Place Ethical Society, on "The menace of under-population," (this title was used for the later, 1936 edition of the book she first published in 1934). The news bulletin announcing her talk included a summary, and a brief outline that included the following statement:

The diminishing birth rate can be increased by creating economic incentives to have children. (South Place Ethical Society 1934).

Despite criticism of her population projections, Charles had professional and friendly contact with scholars of the 1930s, (such as Blacker, and others), and she continued to write and publish in the population field in the latter half of the 1930s.

In 1937, Hogben moved to the University of Aberdeen in Scotland as Regius Professor of Natural History, and the family settled in Aberdeen.

\section{The University of Aberdeen, Scotland, and other Travels 1937 - 1940}

In this period Charles is described as "Leverhulme Research Fellow," Department of Natural History, University of Aberdeen.

(In 1938, the book Political Arithmetic, edited by Hogben, was published; it included chapters authored and coauthored by Charles. It had been prepared at their previous appointment at LSE). 
Charles and Hogben were both listed as "participants" in the Seventh International Genetical Congress. Originally designed to take place in the USSR in 1937, it was postponed to 1938, and, when this second plan fell through, it was hurriedly reorganized by a committee of the Genetical Society of Great Britain to take place in Edinburgh in September 1939. (See official proceedings in a supplementary volume of the Journal of Genetics, 1941). Both Charles and Hogben were listed as "official presenters" of specific papers in different sessions, but apparently, only Hogben attended (I have not been able to verify whether Charles did or did not attend). However, just as the Congress was drawing to a close in September 1939, the Second World War broke out in England, and this precipitated sudden and lasting changes in the lives of Charles and her four children.

\section{War and Consequences for the Family}

When the meetings ended, Charles's oldest daughter, Sylvia (who was working for her father that year, before entering university) had accepted an invitation from a family friend, Gunnar Dahlberg, to return with him to Upsalla, Sweden, to visit, and perhaps work for his family as an "au pair," and then by Christmas, to go on to Oslo to visit other family friends (Hogben 1998, 160).

However, in the early months of 1940 , it seemed doubtful that the Scandinavian countries would remain neutral. So Hogben left Aberdeen for (what he described as) a "busman's holiday" lecturing at the universities in Oslo (Norway) and Copenhagen (Denmark) on the "genetic credentials of Nazi race theory." In fact, his main purpose was to rejoin his daughter in Oslo and bring her back to Britain with him.

Hogben related that when the Nazis marched into Oslo in April 1940, he could not escape Norway by a direct air route home to Britain, since the Oslo airport was being bombed. This was why father and daughter became involved in a trip that lasted just about a year ! It took them from Oslo to Stockholm, then to Moscow, and from there to Vladivostock. They also touched down in Japan and Honolulu, Hawaii. Hogben recorded notes about these travels and these appeared as the book Author in Transit, in the U.S. only (Hogben 1940). From Honolulu, father and daughter went to San Francisco, then to New York, and finally reached their goal, the University of Wisconsin in Madison, Wisconsin, where Hogben had accepted a semester's visiting professorship. (The couple's second-oldest child, Adrian, had left Scotland in 1939 at the age of 17, to study medicine). In this 1940 book, Hogben explained how, going separate ways, he and his wife arrived on the American continent at about the same time, but at 
Sylvia Wargon

different places. Charles had accepted an invitation to undertake a study of differential birth rates in Canada. When the time came, because of the outbreak of war, she cancelled arrangements to leave the two youngest children in private schools in England, and brought them with her on the 1940 trip to Canada by sea.

By the time Charles arrived in Canada with the two youngest children, Hogben and daughter had settled in at the University of Wisconsin. The war and the "separate" professional arrangements of husband in the US and England, and wife in Canada, kept them apart from 1940 to about the middle of 1946, except for two exchanges of visits at the end of 1940. Hogben arrived back in England, when his boat docked in Liverpool in late February 1941.

In the meantime, Charles, with her daughter Clare, and son David, then about 16 and 11 years of age respectively, went directly from Quebec City where they had landed, to London, Ontario, to stay with Lionel Penrose, who had sponsored their immigration to Canada. Charles then traveled to Ottawa, leaving the two children with the Penroses. However, the youngest child, David, rebelled and threatened to run away if left in London. So he was brought to Ottawa where he remained with his mother until she left for Birmingham to join Hogben in 1946. (David remained in America at that time).

\section{Charles in Canada in 1940 and Birmingham, England 1946}

Although the original arrangements for Charles's stay in Ottawa were for one year only, the war took longer than anticipated, and was likely the reason for Charles staying in Canada until 1946.

\section{Charles in Canada 1940 - 1946}

On her arrival in Ottawa in 1940, Charles was identified almost immediately with the Dominion Bureau of Statistics or DBS (as Statistics Canada was then known), where she worked from her arrival in 1940, subsidized by American funding groups for about the first two years. She came "on staff" as a "paid" bureau official when these funds ceased in 1942, and was paid until she left, in 1946.

Charles's arrival at the bureau coincided with certain important demographic data initiatives undertaken in the early 1940s. For the very first time in Canada, questions on nuptiality, fertility and internal migration were included on the 1941 decennial Census questionnaire. (Questions on migration had appeared on 
the quinquennial census forms before and after 1941, but this was the first time migration was included on the 1941 decennial Census form. The new fertility and nuptiality questions were introduced to obtain data on births for longer periods of time, and in greater depth and detail than was possible with the vital statistics. In addition, three questions on present and former residence were designed to measure the considerable movement of population during the 1930s, when international immigration into Canada declined because of bad times everywhere (Canada 1945, 32, 33).

Charles authored analytical studies on Canadian nuptiality and fertility, contributed them to standard DBS volumes (census volumes, Canada Year Book, etc.), and also published articles in scholarly journals in Canada and abroad. Using the 1941 Canadian Census fertility and nuptiality data in the monograph, she documented and explained the reasons for the changing birth rate in Canada, and the differentials in childbearing according to religion, residence, education and profession (1948), This monograph became an important milestone in Canadian demography, despite its unavoidably 'erroneous' projections (already discussed).

Charles also contributed to the evaluation of the Canadian census and vital statistics. Her efforts in connection with the preparation of Canadian divorce statistics are also a matter of record. In addition, Charles lectured at (what was then known as) Carleton College, later Carleton University. A summary of the course she gave in 1943-1944 (probably the only time): Population trends and social policy, describes what must have been an unusually interesting lecture series in Ottawa at that time.

Charles also prepared a brief outline for a proposed study of "social linguistics" (found among papers in early STC files and archives). Her Suggestions for a monograph on Social Linguistics in the early part of 1945, show that, even then, her thinking was never limited solely to fertility and population projections. Obviously the bureau did not go ahead with her proposal, since, despite the Chief Statistician's reply (dated February 10, 1945) acknowledging and discussing her proposal, nothing further came of it. The only monographs published in connection with the 1941 Census were those by Charles (1948) and Hurd, though the latter a monograph was only published about 20 years later, in 1965.

Charles's influence on Canadian census and vital statistics persisted long after she left Canada in 1946. The rich sources of census data on age at marriage, fertility and migration that appeared in the 1941 Canadian census volumes were largely due to her efforts; they provided the basic information for her 1948 monograph, and also stimulated other demographic research by Canadians and 
Sylvia Wargon

non-Canadians alike. So that, even in the late 1960s, at population conferences in the US and elsewhere, demographers greeted Canadians with the question: "Whatever happened to Enid Charles?", implying that her work represented demographic research in Canada. (This actually happened to me at a Population Association of America meeting in the late 1960s !). This was not far from the truth: in this period, there were very few doing in-depth demographic research in Canada, and none were as intensively involved in fertility research as Charles, though the discipline was not yet taught on a regular basis in the universities. Yet from 1940 to 1946 Charles did both: she taught demography and published population research results. She had training and experience that were in very short supply in Canada in the 1940s. Her devotion to work and considerable productivity helped "get things started" in this country under federal government auspices.

Charles was 45 when she arrived in Ottawa in the summer of 1940, and 51 when she left for Birmingham about 6 years later.

\section{The University of Birmingham. 1946 to 1953}

Charles left Ottawa (sometime) in early 1946, to rejoin Hogben, then at the University of Birmingham. She arrived there without a specific arrangement for work. Eventually, she was appointed to a position in the newly-opened Birmingham City Council's Statistical Office (in 1947), and other opportunities for demographic work came along in 1948 (Reader in demography and vital statistics at the Univ. of Birmingham), and in 1949, (as Chief Statistical Officer with two Birmingham hospitals (International Who's Who, 1949).

\section{WHO: Aug. 1953 to First Retirement (1959), and Final Retirement (1964).}

In August 1953, Charles is reported to have commenced work for the World Health Organization. The latter organization gave her various postings as a Regional Advisor in Epidemiology and Health Statistics, and as a Population Statistics Consultant, first in Singapore from August 1953 to 1955, and then in New Delhi, from August 1955 to about December 1959). [Note: Singapore and New Delhi were only two WHO "centers" from which she made working visits to many distant locales in southeast Asia -- to India, and also to (what were then known as): Afghanistan, Ceylon (later Sri Lanka), Burma (later Myanmar) and Thailand].

Beginning in 1956, there is a record of 24 reports documenting these assignments. (The WHO asked me to include, in anything I published, the 
information that these reports can be examined by appointment, in the Permanent Collection of the WHO Library in Geneva). Because of considerable detail in scholarly "annexes", these reports are often twice as long as noted. This is remarkable, since she spent a maximum of about three weeks in most postings, and often, far less time at every posting. Yet the quality of the reports are noteworthy: as good as any of her published materials.

The titles and contents of these reports indicate treatment of a wide variety of very practical subject matters. For example, the $4^{\text {th }}$ report is impressive in tackling: "Afghanistan's five year plan. Proposed guiding principles for the development of health statistics." The $18^{\text {th }}$ report on a field visit to Thailand was in connection with a "...hospital statistics project..." The $23^{\text {rd }}$ report, prepared in Lucknow, Uttar Pradesh, India was entitled: "Comparison of coded and uncoded classification of outpatient morbidity: A study of 2,000 diagnoses. Reorganization of rural health records and reports."

The two reports, for Burma (Myanmar) and Thailand, sent to me as a courtesy by the WHO, include, in addition to accounts of the complex systems of vital statistics reporting in the regions visited, her recommendations for improvement, pertinent annexes, and detailed diaries of the visits. They show that she worked a 6- or 7-day week, traveling to various regions in the countries visited, speaking with two or, usually, more local officials a day. They are evidence that she traveled widely, and are documented proof of the unbelievably detailed nature of her investigations.

When Charles retired for the first time at the end of 1959 (she was then close to 65 years of age), she joined her children, all by then living in the United States. Apparently, she continued to carry out assignments there for the WHO as a 'Consultant' until the end of 1962. These "temporary appointments," are documented, and are proof that she traveled widely and contributed to the methods of collection and record keeping of the statistical situations she encountered in the regions of the countries visited (WHO report, 1984)

After a time, because of her extreme opposition to United States policy in Vietnam and obviously, still a "person of principle", Charles arranged to return to England, where she moved into a retirement community, and became a resident in a nursing home in Torquay. She passed away on March 26, 1972 at the age of 77. Always extremely thin, she broke her hip in a fall, and eventually this contributed to her death due to heart failure. (Hogben passed away three years later, in 1975). 
Sylvia Wargon

\section{What can We Conclude about the 'Career' and Legacy of Enid Charles?}

Without a doubt, Enid Charles was an important pioneer and innovator who worked as a demographer and population statistics specialist in both developed and developing countries, until she was almost 70 years of age. With this WHO work from 1953 to about 1964, Charles was one of the earliest players, if not the earliest, on the international scene, years before the closing decades of the $20^{\text {th }}$ century, when this work actually got underway!

Simon Szreter had noted (1996) that she was important in the 1930s, in disseminating the seminal ideas of early French demographers (such as Arsène Dumont and Adolphe Landry) whose work was then ignored or by-passed in England. She also cited the work of her contemporaries in Europe, Asia and North America, etc., giving her work an "international" flair.

As for her 1934, 1935 and 1936 population projections, they had the same deficiencies and drawbacks as other projections prepared in this period in Great Britain and North America. Because they were based on the years from 19211939, they failed to foresee the post-Second World War 'marriage' and 'baby' booms. Thus, the estimates of the growth and size of predicted western populations were "way off the mark." This created the much-publicized lack of confidence in these forecasts.

However, reputed scholars over the last 50 years - as early as 1955, like Hajnal, and as recently as 2004, like Teitelbaum have indicated that it would have been impossible for anyone of Charles's era to have predicted otherwise. The result was that there has been a considerable change in what is currently expected of population projections, which continue to be calculated and used today.

In the early 1940s, her contributions to demography in Canada were considerable, though she was in this country only six years. This has always been recognized here. But Canadians, like everyone else have been oblivious to what she did after she left Canada!

In the 1950s and 1960s (after working in Birmingham as a demographer until about 1953), she was a population statistics specialist for the WHO in the Far East. There, she applied her expertise to the subjects and problems of the compilation and administration of population statistics in a number of less welldeveloped, (or "third-world") societies. The record of this WHO population consultation work is very impressive: not only for the extensive traveling involved, but also for the contributions, in the 24 reports she prepared, on widely differing subjects, to the organization and/or reorganization of statistical 
activities in many Far East regions. As already indicated, the contents, organization and scope of these reports, as well as their quality, are impressive. It is truly unfortunate that this work has been so inaccessible to the public until now. Her 24 reports are proof of the breadth and quality of the work she did for the WHO, from 1953 to final retirement.

She was an important pioneer and innovator who worked as a demographer and population statistics specialist in both developed and developing countries around the world. She also cited the work of her contemporary social and behavioural scientists in Europe, Asia and North America--anthropologists, demographers, geneticists, psychologists, sociologists, etc., about whose work she was very knowledgeable. This is evident in her 1948 monograph, or indeed in any of her publications. Moreover, working as a population statistics specialist for the WHO in the Far East, she applied her expertise to the subjects and problems of the compilation and administration of population statistics in a number of less well-developed (previously known as "third world") societies.

Thus in her scholarly research and in the pursuit of professional activities as a population statistics specialist, she was one of the earliest "players" on the international scene, years before the closing decades of the $20^{\text {th }}$ century when "global" interests and issues first began to dominate scholarly activities and research in the social sciences.

\section{Acknowledgement:}

Paper presented on invitation to the "Distinguished Demographer" Series, on November 19, 2004, Sociology Department, University of Alberta, Edmonton, Alberta. Sponsored by the Society of Edmonton Demographers.

\section{End Notes:}

1. For economy, citations of this book by Adrian Hogben and Anne Hogben are attributed simply to Hogben 1998.

2 I have not been able to find this book in Canada, but I did find it in England when I was there in 1998. I would appreciate being told about any copy available in North America. 
Sylvia Wargon

\section{References:}

Charles, Enid, 1934a. The Twilight of Parenthood: A Biological Study of the Decline of Population Growth. London: Watts and Company.

Charles, Enid, 1934b. The Twilight of Parenthood.: (published without subtitle in the US only). London: W. W. Norton and Company.

Charles, Enid, 1936. The Menace of Underpopulation: A Biological Study of the Decline of Population Growth. London: Watts and Company.

Charles, Enid, 1946. The Changing Size of the Family in Canada. 1941 Census Monograph. Ottawa: Dominion Bureau of Statistics.

Conrad, Peter, 1977. "Public eyes and private genes: Historical frames, new constructions and social problems." Social Problems, 44(2), pp. 139-154.

Cott, Nancy F., 1987. The Grounding of Modern Feminism. New Haven, Connecticut Yale University Press.

Dahrendorf, Ralf, 1995. LSE A History of the London School of Economics and Political Science 1895-1995. Oxford: Oxford University Press.

Grebenik, Eugene, 1991. "Demographic research in Britain 1938-1986," in Population Research in Britain. A supplement to Population Studies, 45 edited by M. Murphy and J. Hobcraft, The Population Investigation Committee, London School of Economics.

Grebenik, Eugene, 1997. Personal letter.

International Who's Who, Various years: 1973, 1973-1974. 1973-1974 is the $37 \mathrm{t}$ edition. Europa Publications.

Hogben, Adrian, 1998. Lancelot Hogben, Scientific Humanist, an unauthorized autobiography, edited by Adrian and Anne Hogben, Rendelsham Mews, Woodbridge, Suffolk IP12: The Merlin Press, Ltd.

Jones, Greta, 1980. Social Darwinism and English Thought. The Interaction between Biological and Social Theory. Brighton, Sussex: Harvester Press; Atlantic Highlands, NJ: Humanities Press.

Jones, Greta, 1986. Social Hygiene in $20^{\text {th }}$ Century Britain. London and New Hampshire: Croom-Helm. 
Kevles, Daniel, 1986. In the Name of Eugenics: Genetics and the Uses of Human Heredity. Berkeley, California: University of California Press. (first published in 1985). This is the book following the series of four articles that appeared in the New Yorker, in the section, "Annals of Eugenics" on the following dates: October 8, 15, 27, and 29, 1984.

Keyfitz, Nathan, 1993. Personal letter.

Lewis, Jane, 1980. The Politics of Motherhood. Child and Maternal Welfare in England, 1900-1937. London: Croom Helm and Montreal, McGill University Press.

Lewis, Jane, 1984. Women in England, 1870-1950: Sexual Divisions and Social Change. Sussex: Wheatsheaf Books and Bloomington: Indiana University Press.

Notestein, F.W., Irene B. Taueber, Dudley Kirk, Ansley Coale and Louise K. Kiser, 1944. The Future Population of Europe and the Soviet Union: Population Projections, 1940-1970. Geneva: League of Nations.

Pearson, E.S. and M.G. Kendall (Eds.), 1970. Studies in the History of Statistics and Probability. Darien, Connecticut: Hafner Publishing Company.

Proceedings of the Seventh International Genetical Congress. 1941. Contemporary Trends in Differential Fertility. Issued as a supplementary volume to the Journal of Eugenics, Cambridge, at the University Press. This Congress was heald in September, 1939 in Edinburgh, Scotland. Available in the library of the federal Department of Agriculture.

South Place Ethical Society, 1934.

Wells, G.P., 1978. "Lancelot Thomas Hogben". Biographical Memoirs of Fellows of the Royal Society. Vol. 24. London: The Royal Society.

Whetham, E., 1993. The Newnham College Roll Letter, page 56. 